\title{
Measuring and Explaining the Distributive Effects of Rural Tax and Fee Reform in Anhui Province
}

\section{Christian Göbel}

\section{(2) OpenEdition \\ Journals}

\section{Electronic version}

URL: http://journals.openedition.org/chinaperspectives/3763

DOI: 10.4000/chinaperspectives.3763

ISSN: 1996-4617

\section{Publisher}

Centre d'étude français sur la Chine contemporaine

\section{Printed version}

Date of publication: 4 April 2008

Number of pages: $58-74$

ISSN: 2070-3449

\section{Electronic reference}

Christian Göbel, « Measuring and Explaining the Distributive Effects of Rural Tax and Fee Reform in Anhui Province », China Perspectives [Online], 2008/2 | 2008, Online since 01 April 2011, connection on 28 October 2019. URL : http://journals.openedition.org/chinaperspectives/3763 ; DOI : 10.4000/ chinaperspectives.3763 
$[7$

Measuring and Explaining

\title{
the Distributive Effects of
}

\section{Rural Tax and Fee Reform in}

\section{Anhui Province}

\author{
CHRISTIAN GÖBEL
}

This paper focuses on the distributive effects of the Rural Tax and Fee Reform on county-level aggregate peasant burden, peasant income, and government finances in China's Anhui Province. It seeks to answer the question of whether the reform has changed the structural determinants of peasant per capita income and government revenue. It further tackles the question of who actually benefited during the reform period, who did not, and if the changes in average county-level peasant per capita income (PPCI) and government receipts were indeed results of the reform, or if they were brought about by other, unrelated factors.

\section{The Rural Tax and Fee Reform}

$\Omega^{\prime}$ ince the early 1990s, the number of rural protests, petitions, and large-scale riots has been rapidly rising, causing deep worry in the top echelon of the Chinese Communist Party (CCP). According to official figures, the number of "mass incidents" increased 28 percent between 2003 and 2004 alone. ${ }^{(2)}$ As excessive extraction of fees and taxes and illegal farmland seizures are the main reasons for these problems in rural China, efforts have been made to reduce the peasant burden, improve local governance, and reduce the ever-increasing wealth gap by developing the countryside. The Rural Tax and Fee Reform (nongcun shuifei gaige; henceforth: RTFR) is the latest of these efforts, and the name belies the scope of institutional change it has come to entail.

In spite of what the name implies, the RTFR was more than a minor policy aimed at reducing farmers' financial burdens by standardising fiscal extraction and gradually phasing out agricultural taxes. ${ }^{(3)}$ Policy-makers realised that sustained burden reduction could not be achieved without substantive institutional change. As one document put it:
The Rural Tax and Fee Reform not only implies the regulation of the distributive relationship between national and peasant income; it is a major transformation of the village superstructure. ${ }^{(4)}$

One crucial component of the reform package, the so-called "complementary reforms" (peitao gaige), ${ }^{(5)}$ represents an effort at local-level institution-building unprecedented since the

1. This is a completely revised version of a paper delivered at the International Conference on Development Challenges in Rural China, University of International Business and Economics, Beijing, 25-26 October 2007. The author expresses his gratitude to the CEFC for the financial support that enabled him to attend the conference.

2. See Wang Dejun, "Quntixing shijian duo fa jidai guanzhu" (Rising mass protests cause urgent concern), Ta Kung Pao, 6 July 2005).

3. Unless otherwise indicated, I follow the practice of the national and provincial statistical yearbooks and refer to the agricultural, animal husbandry and agricultural special products taxes simply as "agricultural taxes."

4. Guobanfa (2002) No. 25. Guowuyuan Bangonting guanyu zuohao 2002 nian guangda nongcun shuifei gaige shidian gongzuo de tongzhi (Notification by the General Office of the State Council concerning the orderly expansion of the Rural Tax and Fee Reform tria areas in 2002).

5. See Zhongfa (2000) No. 7. Zhonggong Zhongyang, Guowuyuan guanyu jinxing nongcun shuifei gaige shidian gongzuo de tongzhi (Notification by the Central Committee of the Communist Party of China and the State Council concerning the advancement of work in Rural Tax and Fee Reform trial areas). The distinction between the "main reform" (zhuti gaige) and "complementary reforms" (peitao gaige) is maintained throughout all policy documents concerning the RTFR. 
establishment of the communes in the late 1950s. The RTFR was aimed not only at restructuring, but also at building anew local-level government structures with the ultimate aim of improving state distributive performance and thus defusing the critical situation caused by what is commonly known as the "three rural problems" ( san nong wenti). ${ }^{(6)}$ The RTFR has proceeded in four stages to date. Between 1993 and 2000, more than 50 counties in seven provinces experimented with alternative tax and fee models. Due to a policy blunder committed by then-premier Zhu Rongji, most of these experiments had to be suspended in 1998. ${ }^{(7)}$ Two years later, however, the central government presented a compulsory reform model that was initially implemented only in Anhui Province. This policy mandated the abolition of most regular and irregular fees, offset by tripling the agricultural tax. Despite the grave problems that the steep reduction of local fiscal revenue caused Anhui Province during the first two reform years, the policy was extended to trial counties across China and was finally implemented nationwide in 2003. At this point, official statistics put the average burden reduction at 45.8 percent. ${ }^{(8)}$

Because the reform bore serious flaws, however, actual burden reduction was actually far below this percentage in many places and for many individuals, with local economic development being, according to Bernstein and Lü, the major intervening variable. ${ }^{(9)}$ This prompted policymakers to announce grain subsidies and the gradual phasing out of the agricultural tax and the agricultural special products tax in early 2004, only one year after the initial policy was implemented nationwide. Tax and fee burden dropped another 44.3 percent between 2003 and 2004, to only 1.3 percent of total average peasant income. ${ }^{(1)}$ In order to compensate for the resulting losses, the next step was to forcibly implement the so-called "complementary reforms." Townships and towns were ordered to reduce personnel; townships and villages were merged, as were primary and secondary schools. Local bureaucracies were to be restructured, administration to be rendered more transparent and efficient, responsibilities and resources to be redistributed. (II) So far, however, with the exception of the mergers of villages and of townships, these reforms have been successfully circumvented by most counties, and where they have been implemented, they have actually yielded no significant reduction in outlays. Instead, centrallevel subsidies have been increased steeply in order to bail out the severely indebted counties, townships, and villages.

A great number of studies describe the adverse effects brought forth by the reform. In particular, many grassroots governments were deprived of vital fiscal resources, which seriously affected local service provision. As John James Kennedy shows, many township governments were "hollowed out" by the reform and found themselves forced to limit the provision of already precarious social services such as compulsory education, social security payments, and medical subsidies. ${ }^{(12)}$ Brandt et al.'s survey of 50 towns and 100 villages in five provinces confirms that "the fiscal reforms have undermined, or at least not improved, the current budgetary condition of townships." ${ }^{(13)}$ Most importantly, their study shows that the impact of the reform varied significantly across China and between richer and poorer townships. This is confirmed by other surveys as well. ${ }^{(14)}$ Clearly, the aggregate burden reduction figures cited above are not an accurate reflection of the impact of RTFR on government and society at the county level and below.

Because a thorough investigation of the implementation process of the RTFR and its effects on local governance and central-local relations has been made elsewhere, ${ }^{(15)}$ this paper seeks to deepen our understanding of the reform

6. The "three rural problems" refers to peasant poverty (nongmin wenti), the stagnation of rural (social) development especially when compared with the cities (nongcun went), and the lack of competitiveness of the agricultural sector (nongye went). The expression is attributed to Li Changping, a former county chief, who wrote a letter to then-premier Zhu Rongji to draw attention to these issues. The letter contained the phrase, "the villages are really poor, the peasants' life is really hard, and the situation of agriculture is really precarious" (noncun zhen qiong, nongmin zhen ku, nongye zhen weixian). See Li Changping, Wo xiang zongli shuo shihua (I spoke the truth to the premier), Beijing, Guangming ribao chubanshe, 2002, preface.

7. See Chen Guidi et al., Zhongguo nongmin diaocha (An inquiry into the situation of China's farmers), Beijing, Renmin wenxue chubanshi, 2004.

8. Zhu Shouyin et al., "Nongcun shuifei gaige shidian he xiangcun guanli tizhi gaige genzong yanjiu baogao" (Follow-up research report on the Rural Tax and Fee Reforms Trial Areas and Rural Administrative System Reforms), Jingji Yanjiu Cankao, vol. 40, 2003, pp. 2-24.

9. Thomas P. Bernstein et al., Taxation Without Representation in Rural China, Cambridge/New York, Cambridge University Press, 2003.

10. Li Lihui, "Nongye shui jian jiuchengsan, nongmin jianfu 200 yi" (Agricultural tax reduced 93\%, peasant burden reduced 20 billion yuan), Renmin Ribao, 24 May 2005.

11. See Zhongfa (2000) No. 7, op. cit.

12. John James Kennedy, "From the Tax-for-Fee Reform to the Abolition of Agricultural Taxes: The Impact on Township Governments in North-west China," China Quarterly, vol. 189, 2007, pp. 43-59.

13. Loren Brandt et al., "China- Rural Public Finance. The Township Perspective. Annex 8: World Bank Report. Fiscal Reform and Role of the Township," http://iisdb.stanford.edu/pubs/21662/Township_Finance_2006.pdf, 2006 (accessed on 7 April 2008).

14. See for example Wang Bing et al., "Nongcun shuifei gaige dui zhongxi bu xiangzhen cail yingxiang de shijian yanjiu - jiyu 4 sheng 8 xian chouyang diaocha shuju de fenxi" (Empirical research on the fiscal impacts of the RTFR on central and western Chinese townships and towns), Guanli Shijie, vol. 11, 2006.

15. See for example Christian Göbel, "The Peasant's Rescue from the Cadre? An Institutional Analysis of China's Rural Tax and Fee Reform," in Thomas Heberer et al. (eds.), Institutional Change and Political Continuity in Contemporary China, London/New York, Routledge, forthcoming; and Linda Chelan Li, "Working for the Peasants? Strategic Interactions and Unintended Consequences in the Chinese Rural Tax Reform," China Journal, vol. 57, 2007, pp. 89-106. 
Table 1. Peasant per capita burden and income, 1999-2005

\begin{tabular}{l|c|c|c|c|r}
\hline \hline & $\begin{array}{c}\text { Burden per } \\
\text { Capita 1999 }\end{array}$ & $\begin{array}{c}\text { Burden per } \\
\text { Capita 2003 }\end{array}$ & $\begin{array}{c}\text { Peasant PCI } \\
1999\end{array}$ & $\begin{array}{c}\text { Peasant PCI } \\
\text { 2003 }\end{array}$ & $\begin{array}{c}\text { Peasant PCI } \\
\text { 2005 }\end{array}$ \\
\hline Mean & 109.9 & 58.9 & 1971.8 & 2087.2 & 2702.3 \\
\hline Std. Deviation & 18.9 & 16.7 & 348.7 & 491.2 & 682.6 \\
\hline $\mathrm{N}$ & 61 & 61 & 61 & 61 & 61 \\
\hline Minimum & 67.4 & 32.0 & 1104.0 & 1211.1 & 1492.9 \\
\hline Maximum & 163.3 & 116.9 & 2548.0 & 2964.0 & 4397.6 \\
\hline Inequal Quot & 17.2 & 28.4 & 17.7 & 23.6 & 25.3 \\
\hline
\end{tabular}

Source: Anhui Statistical Yearbook, 2000 and Anhui Province, RTFR LSG, Anhui Sheng nongcun shuifeigaige qianhou nongmin fudan qingkuang biao (Situation of Peasant Burden Before and After the Rural Tax and Fee Reform in Anhui Province), 2002, internal reference.

process and its outcomes by focusing on the distributive effects of the reform on the aggregate peasant burden, peasant income, and government finances at the county level in China's Anhui Province. This level of analysis has been chosen mainly because comprehensive data for the township and village level is not available. That being said, most townships suffered from the impacts of the RTFR, and bearing in mind that even townships within one county display widely differing levels of development, such an analysis might at first seem unsatisfactory. Allowing for these limitations, other reasons favour such an analysis. First and foremost, unlike all other administrative levels except for the centre, the county enjoys considerable discretion in designing and implementing policies. Understanding how internal and external factors affect policy-making at this level is crucial for delineating the potential of the county to implement coherent policies. Second and relatedly, the extent to which a county government is affected determines its ability to level out the negative effects of the reform on townships, villages, and even households. To sum up, the county must be considered the primary local-level development agency, and analysis will provide insights not only into the nature and determinants of differences within counties, but also into the factors that hinder or further their ability to adequately play the role of an agent of development.

The first part of this paper is descriptive and outlines the aggregate changes in peasant burden, peasant per capita income, and government receipts during all phases of the reform. As these sections will make clear, peasant burden has decreased and peasant income increased, but considerable variation underlies these changes. The same is true for government finances. The second part statistically analyses data for Anhui's 61 counties in order to provide explanations for these phenomena. First, it seeks to answer the question of whether the reform has changed the structural determinants of peasant per capita income and government revenue, for example by financially strengthening those regions that were primarily dependent on agriculture. Second, it tackles the question of who actually benefited during the reform period, who did not, and if the changes in average county-level peasant per capita income (PPCI) and government receipts were indeed results of the reform, or if they were brought about by other, unrelated factors. The last question concerns governments that were able to increase their expenditures either because they were able to shoulder the reform costs or because they received additional transfer payments: Given the new focus on rural development, have their expenditure structures changed?

\section{Aggregate development of peasant income and government finances, 1999-2005}

This section provides a glimpse of peasant burden, peasant income, government revenue, government expenditures, and spending on social services one year before the reform began (1999), in the year preceding the decision to scrap the agricultural tax (2003), and after the tax was abandoned almost everywhere in Anhui (2005). However, such descriptive statistics do not prove that these changes were a direct or even indirect result of the RTFR. Indeed, negative 
Table 2. Budgetary revenue and expenditures, 1999-2005

\begin{tabular}{l|r|r|r|r|r|r}
\hline \hline & $\begin{array}{c}\text { Rev2/Cap1 } \\
1999\end{array}$ & $\begin{array}{c}\text { Budget } \\
\text { Rev/Cap } \\
\mathbf{2 0 0 3}\end{array}$ & $\begin{array}{c}\text { Budget } \\
\text { Rev/Cap } \\
\mathbf{2 0 0 5}\end{array}$ & $\begin{array}{c}\text { Budget } \\
\text { Exp/Cap } \\
1999\end{array}$ & $\begin{array}{r}\text { Budget } \\
\text { Exp/Cap } \\
2003\end{array}$ & $\begin{array}{r}\text { Budget } \\
\text { Exp/Cap } \\
2005\end{array}$ \\
\hline Mean & 243.1 & 182.0 & 226.9 & 304.5 & 441.4 & 682.5 \\
\hline $\begin{array}{l}\text { Std. } \\
\text { Deviation }\end{array}$ & 63.3 & 85.00 & 171.3 & 78.3 & 185.9 & 324.5 \\
\hline N & 61 & 61 & 61 & 61 & 61 & 61 \\
\hline Minimum & 144.6 & 64.2 & 41.0 & 184.8 & 208.1 & 309.5 \\
\hline Maximum & 446.6 & 498.0 & 1013.8 & 531.4 & 1016.7 & 1709.2 \\
\hline Inequal Quot & 26.0 & 46.7 & 75.5 & 25.7 & 42.1 & 47.5 \\
\hline
\end{tabular}

1. For the year 1999, the important, yet non-budgetary receipts from the village levy, the township comprehensive fee and the education fund are added to that year's budgetary revenue. This adjusted revenue will be referred to as Rev2 throughout this paper. The same method will be applied to correct expenditures (Exp2). Peasant burden for 1999 will be calculated by calculating the percentage of all agriculture-related regular taxes and fees in Rev2. Since all non-budgetary levies were abandoned in 2000, such adjustments are not necessary for the following years. It suffices to relate the receipts from agricultural taxes, which have all become budgetary revenue, to total budgetary revenue of that year

Source: Anhui Statistical Yearbook, 2000 and Anhui Province, RTFR LSG, Anhui Sheng nongcun shuifeigaige qianhou nongmin fudan qingkuang biao, op. cit.

indicators might be the result of external factors as diverse as China's WTO accession in 2001, the severe flood that swept across the country in 2003, or even policies implemented concurrently. It is possible that the reform mitigated the impact of such events, even if indicators suggest otherwise. Conversely, increasing peasant per capita income might not be a result of the reform, but of increased migrant labour. Such causalities will be addressed by inferential statistics in the second part of the paper.

As Table 1 shows, the reform significantly reduced the peasant burden in Anhui's 61 counties already during the first reform phase.

Extractions from Anhui's farmers fell from an average of 110 RMB per person to $59 \mathrm{RMB}$, a decrease of around 47 percent. At the same time, however, the margin of affectedness became wider. Although average burden declined drastically between 1999 and 2003, the standard deviation from this average for all 61 counties remained almost constant. These two values can be used to construct an "coefficient of variation." If the standard deviation is low in relation to the mean, this average comes close to the actual situation in most counties. If the standard deviation as a percentage of the average rises, however, this means that an increasingly large margin underlies that average. When applied to peasant burden, we see that it became more unequal across the 61 counties. The standard deviation equalled 17.2 percent of the average in 1999, but rose to 28.4 percent in 2003.

An examination of peasant income at these three points in time yields a similar picture. On the one hand, average PPCI grew steadily from an average of 1,972 RMB per person in 1999 to 2,087 RMB four years later, and to 2,702 RMB in 2005. At the same time, however, income inequality increased. This can again be gauged from the coefficient of variation, which increased from 17.7 percent in 1999 to 23.6 percent in 2003 , and continued to rise slightly until 2005.

As for revenues and expenditures, what strikes the analyst first is that total per capita revenue decreased between 1999 and 2005 (with a sharp drop in 2003), but that per capita budgetary expenditures more than doubled during the same time period (Table 2).

In fact, what characterises the reform period is that the ratio of county revenues to expenditures increased rather steeply after 1998. While Anhui's county-level expenditures exceeded revenues by an average of around 27 percent in 1998, this ratio increased more than ten-fold within only seven years! ${ }^{(16)}$ Applying the "coefficient of variation" introduced above, we can see that revenue inequality increased

16. See graph 3 below. 
Table 3. Main components of structural development indicators, 1999

\begin{tabular}{|c|c|c|c|c|c|}
\hline & \multicolumn{2}{|c|}{ Component } & & \multicolumn{2}{|c|}{ Component } \\
\hline & 1 & 2 & & 1 & 2 \\
\hline GDP/Cap99 & .944 & .011 & Electricity/RuralPop99 & .366 & -.143 \\
\hline Secondary/Cap99 & .917 & -.073 & Land/RuralPop99 & .055 & .920 \\
\hline Tertiary/Cap99 & .898 & -.168 & Sown/RuralPop99 & .119 & .901 \\
\hline Nonagripop/TotalPop99 & .834 & .114 & Wage/TotalRurallnc00 & -.125 & -.682 \\
\hline Secondray/TotalGDP99 & .803 & -.198 & Agmach/RuralPop99 & .305 & .677 \\
\hline Primary/totalGDP99 & -.801 & .424 & Primary/Cap99 & .520 & .564 \\
\hline TotalPop99 & -.624 & .341 & Tertiary/GDP99 & .169 & -.526 \\
\hline DrinkingWater/RuralPop99 & .575 & .364 & RuralHouseholdSize99 & -.501 & .510 \\
\hline
\end{tabular}

Extraction method: main component analysis.

Source: Analysis based on Anhui Statistical Yearbook, 2000 and Anhui Province, RTFR LSG, Anhui Sheng nongcun shuifeigaige qianhou nongmin fudan qingkuang biao, op. cit.

steadily throughout the reform period, and especially when the new agricultural tax was gradually being abandoned. Expenditure inequality rose just as steeply during the first reform phase, but not nearly as dramatically in the second phase. Hence, during the first reform phase, the gaps in average peasant per capita income across Anhui widened, and revenue and expenditure inequality at the county government level increased. When the agricultural tax was gradually rescinded, the picture changed. Although the inequalities did not level out, they didn't increase as steeply as before.

\section{The structural determinants of peasant income and government revenue}

What caused these differences and changes? The following sections seek to provide explanations that account for the differences outlined above. In particular, they test two interrelated hypotheses: first, that differences in development are a function of structural factors preceeding the reform. In other words, unequal development has been path-dependent and is unrelated either to the Rural Tax and Fee Reform or to other policies. Second, that the differences were brought about by the reform policies. In order to explore these alternative explanations statistically, a decision must first be made on how to operationalise such "structural" variables, and what other variables to include. For example, a higher PPCI in Eastern Anhui might have been caused by increased economies of scale in agriculture, by peasants migrating to the wealthy neighbouring provinces, or by improved opportunities to engage in sideline occupations. Other variables might be responsible as well, such as socioeconomic and socio-structural factors, involvement in sectors other than agriculture, the social infrastrucure, or natural disasters.

However, running a linear regression that includes all of these indicators would prove fruitless for two reasons: first, including such a large number of variables violates the principle of parsimony, which calls for explaining as much as possible with a model as simple as possible. Second, and more importantly, some of these variables might be inter-correlated, which would skew the outcome and possibly render it meaningless.

In order to reach the dual goal of providing a parsimonious explanation without excluding any of these variables, I will analyse them by means of a factor analysis that includes county-level data listed in the Statistical Yearbook of Anhui Province as well as data I was able to obtain from the Ministry of Finance of Anhui Province. These include various indicators for the economic structure (GDP per capita, percentage of GDP of the three sectors in the local economy; primary, secondary, and tertiary GDP per capita); for the level of socio-economic development (peasant household 
Table 4. Main components of structural development indicators, 2003 and 2005

\begin{tabular}{|c|c|c|c|c|c|}
\hline \multicolumn{3}{|c|}{ Component matrix for the year 2003} & \multicolumn{3}{|c|}{ Component matrix for the year 2005} \\
\hline & \multicolumn{2}{|c|}{ Component } & & \multicolumn{2}{|c|}{ Component } \\
\hline & 1 & 2 & & 1 & 2 \\
\hline SecondaryperPerson 03 & .898 & .248 & PrimarytotalGDP05 & -.909 & .138 \\
\hline TertiaryperPerson03 & .891 & .185 & SecondaryperPerson 05 & .890 & .283 \\
\hline GDPCapita03 & .890 & .320 & TertiaryperPerson05 & .867 & .247 \\
\hline PrimaryTotalGDP03 & -.870 & .031 & SecondrayTotalGDP05 & .848 & .042 \\
\hline SecondaryTotaIGDP03 & .801 & .114 & GDPPerson05 & .837 & .435 \\
\hline TotalPopulation03 & -.779 & -.023 & \multirow[t]{2}{*}{ AvgRuralHouseholdsize05 } & \multirow[t]{2}{*}{-.766} & .171 \\
\hline NonagripopPerc03 & .673 & .453 & & & \multirow{2}{*}{-.222} \\
\hline RuralHouseholdSize 03 & -.672 & .352 & Pop05 & -.717 & \\
\hline \multirow{2}{*}{ DrinkingWaterRuralPop03 } & \multirow{2}{*}{.481} & \multirow{2}{*}{.319} & NonagriPoph & .582 & .501 \\
\hline & & & WagesTotallnc05 & .510 & -.361 \\
\hline ElectricityRuraIPop03 & .347 & .049 & ElectricityRuralPop05 & .477 & .366 \\
\hline TertiaryTotalGDP03 & .279 & -.273 & PrimaryperPerson05 & .042 & .812 \\
\hline SownperPeasant03 & -.404 & .849 & SownperPeasant05 & -.538 & .744 \\
\hline LandperPeasant03 & -.447 & .839 & LandperPeasant05 & -.559 & .732 \\
\hline AgmachPowerRuralPop03 & -.244 & .786 & AgMachPowerRuralPop05 & -.375 & .695 \\
\hline WageTotallnc03 & 302 & -.541 & TertiaryTotaIGDP05 & .229 & -.421 \\
\hline PrimaryperPerson03 & .307 & .508 & DrinkingWaterRuralPop05 & .249 & .317 \\
\hline
\end{tabular}

size, the amount of land each person cultivates, the percentage of persons of the total population not engaged in agriculture, the percentage of wages in peasant income, and the acreage each person sows; employment of agricultural machinery); and more general developmental indicators (access to electricity, access to drinking water, connection to roads). Table 3 summarises the resulting analysis for the pre-reform year 1999.

The factor analysis reveals that there is indeed significant correlation between the considered variables. Only two components explain about 62 percent of their variation. Factor 1 alone explains 37 percent, and table 3 shows that this factor is associated particularly closely with the local economic structure. It correlates very highly with all indicators for non- agricultural economic development in general, and with industrialisation in particular. Interestingly, this factor correlates negatively with the relative size of the primary sector, indicating that industrialisation and agriculture are mutually exclusive. As the analysis reveals, this factor also correlates significantly with development indicators such as access to drinking water, the share of the population not engaged in agriculture, rural household size, and electricity use per capita. This illustrates the large impact of a viable industrial sector for China's development, and it simultaneously illustrates that the size of the tertiary sector does not play a determining role in this respect.

Since Factor 2 correlates very highly with land per person and the sown acreage per person, and also with the amount 
Table 5. Correlation of peasant per capita income 1999 with various variables

\begin{tabular}{l|c|c|c|c|c}
\hline \hline & $\begin{array}{c}\text { Non-agricult. } \\
\text { econ 1999 }\end{array}$ & $\begin{array}{c}\text { Agricult. } \\
\text { econ of scale }\end{array}$ & $\begin{array}{c}\text { PeasantBurden } \\
\text { ICap 1999 }\end{array}$ & $\begin{array}{c}\text { Wages/ } \\
\text { Inc00 }\end{array}$ & $\begin{array}{c}\text { FloodDrought/ } \\
\text { TotalSown99 }\end{array}$ \\
\hline $\mathrm{R}$ (Pearson) & $\begin{array}{c}.638(* *) \\
\text { Signific. (2-sided) }\end{array}$ & .214 & .063 & .058 &. $.349\left({ }^{* *}\right)$ \\
\hline $\mathrm{N}$ & .000 & .124 & .630 & .510 & .006 \\
\hline & 61 & 61 & 61 & 61 & 61 \\
\hline * The correlation is significant at a level of 0,05 (2-sided). & ** The correlation is significant at a level of 0,01 (2-sided). \\
$\begin{array}{l}\text { Source: Anhui Statistical Yearbook, 2000 and Anhui Province, RTFR LSG, Anhui Sheng nongcun shuifeigaige qianhou } \\
\text { nongmin fudan qingkuang biao, op. cit. }\end{array}$
\end{tabular}

Table 6. Correlation of peasant per capita income 2003 and 2005 with various variables

\begin{tabular}{|c|c|c|c|c|c|}
\hline 2003 & $\begin{array}{c}\text { Non-agricult. } \\
\text { econ }\end{array}$ & $\begin{array}{c}\text { Agricult. } \\
\text { econ of scale }\end{array}$ & $\begin{array}{c}\text { PeasantBurden } \\
\text { /Cap }\end{array}$ & Wages/lnc & $\begin{array}{l}\text { FloodDrought } \\
\text { /Sown }\end{array}$ \\
\hline R (Pearson) & $.562\left(^{* *}\right)$ & -.157 & -.057 & $.396\left({ }^{* *}\right)$ & $-.309\left(^{*}\right)$ \\
\hline $\begin{array}{l}\text { Significance } \\
\text { (2-sided) }\end{array}$ & .000 & .227 & .662 & .002 & .015 \\
\hline $\mathrm{N}$ & 61 & 61 & 61 & 61 & 61 \\
\hline \multicolumn{6}{|l|}{2005} \\
\hline R (Pearson) & $.738\left(^{* *}\right)$ & .053 & -.091 & $.339\left(^{* *}\right)$ & -101 \\
\hline $\begin{array}{l}\text { Significance } \\
\text { (2-sided) }\end{array}$ & .000 & .684 & .486 & .000 & .441 \\
\hline $\mathrm{N}$ & 61 & 61 & 61 & 61 & 61 \\
\hline
\end{tabular}

of agricultural machinery employed per peasant and the primary GDP per person, economies of scale in agriculture most likely underlie the second factor. It is interesting to note that the relative size of wage receipts in peasant per capita income correlates negatively with this factor, suggesting that peasants in agriculture-intensive regions are not likely to seek or obtain employment elsewhere. Thus, the initial 17 structural variables have been reduced to merely two, namely non-agricultural economic development and economies of scale in agriculture. Did these structural parameters change in the course of the two reform stages? As Table 4 shows, this was not the case.

As can be seen from Table 4, the factor analysis extracts precisely the two variables that were obtained for the year
1999. There is one remarkable difference in the correlations of the individual variables with the two factors: the wage variable correlated positively with the first factor and negatively with the second. However, while the negative correlation with agricultural economies of scale became less significant over the years, the positive correlation with industrialisation increased. This might signify that in industrialised regions, peasant income increasingly depends on wages.

How well can these factors explain variations in burden reduction, peasant income, and government revenue and expenditure? I will start by looking at their effect on $\mathrm{PPCl}$ and then proceed to analyse their interrelationship with government revenue and expenditure. Table 5 provides the Pearson correlation coefficients for the bivariate correlation of 
these two factors and PPCI in 1999. In addition, it tests the relationship of PPCI with two other important non-structural variables, namely peasant burden and natural disasters (percentage of total sown area that was affected by flood and drought). Furthermore, since the relationship of the percentage of wages to total income to the two factors has changed so remarkably, it will be included in the analysis as a separate variable.

As Table 5 shows, PPCI in 1999 correlates most significantly with an industrialised economy. Contrary to expectations, there is no strong correlation between agricultural economies of scale and PPCI. Nor, it is interesting to note, is the average peasant burden level statistically related to this variable. In other words, high average peasant per capita burden does not automatically lead to low average PPCI, and vice versa. This is a very significant finding, given the common assumption that high peasant burden tends to lead to stagnation of peasant income. It verifies the hypothesis put forward in section four (see "Explaining the changes in peasant income and government finances") that it is income inequality that makes peasant burden a problem, and not the amount of fiscal extractions per se. Since the county-level aggregate figures employed here do not reflect this inequality, they do not correlate with the size of peasant burden. As might be expected, however, the percentage of sown crops destroyed by flood and drought correlates negatively with peasant per capita income. The relative size of wages in gross PPCI, however, did not seem to determine the level of PPCI in 1999.

Did these structural parameters change in the first and second reform phases? Table 6 suggests that this was not the case.

On the contrary, the relationship between $\mathrm{PPCl}$ and industrialisation became even stronger. Agricultural economies of scale, which had not played a significant role to begin with, became even less important. As might be expected, peasant burden did not become important after it had been reduced so much. On the other hand, the proportion of wages in peasant gross revenue started to play a role in 2003. Finally, as might have been expected, natural disasters correlated with PPCI in 2003, but the same is not true for 2005. This is probably due to the fact that Anhui was hit by a severe flood in 2003, which affected harvests especially in the western and southern parts of the province, but no comparable disasters were registered for 2005.

As for total government revenues (including agricultural levies and fees), Table 7 also identifies the level of industrial development as the major determining variable, and the re- lationship seems to have become even stronger during the reform period (Column 1).

While the variation in non-agricultural economic development corresponded with 58 percent of the variation in government per capita revenue in 1999, the percentage steadily increased to 61 percent in 2003 and 67 percent in 2005. ${ }^{(17)}$ The table also shows that, as opposed to 1999, high agricultural economies of scale started to have a slightly negative influence on government revenue after the first reform step (Column 2). Obviously, industry-heavy counties fared increasingly better throughout the reform, while counties where comparatively large plots predominated lost out. As can be seen, these counties were stigmatised during the first reform phase.

As for the relationship between peasant income, peasant burden, and government revenue, the correlations clearly indicate that revenue tended to be high where $\mathrm{PPCI}$ was high as well (Column 3). Since nearly 90 percent of the population at the county level or below is registered as "agricultural population" in the Statistical Yearbooks, this is not surprising; peasants are the chief source of government receipts at this level, and high peasant income is reflected in higher government revenues. However, per capita receipts from agricultural taxes have always been much lower than per capita receipts from industry- and service-related taxes, and counties relying chiefly on agricultural taxes and with few or no other sources of income tended to be poorer than those endowed with a large percentage of non-agricultural receipts (Column 4). Dependence on peasant burden was therefore a hallmark of the relatively poorer counties. The same logic applies to per capita expenditures. This confirms the observation made by Thomas Bernstein and Xiaobo Lü that local economic development has been the major intervening variable determining the impact of efforts to reduce peasant burden. ${ }^{(18)}$ Prosperous provincial-level "Eastern" (dongbu) governments such as Shanghai, Guangdong, or Jiangsu, with a sound non-agricultural revenue base, could easily bear the cost of the reforms, while most counties in the so-called "Central" (zhongbu) provinces depended mainly on extractions from peasants for revenue. As the previous paragraph has shown, these observations also hold true at the county level. Naturally, this situation had changed by 2005; almost all rural taxes and fees had been rescinded, and expenditures had to be funded from other sources.

17. The percentage-measure ( $r$-square) is derived by multiplying the correlation coefficient with itself.

18. Thomas P. Bernstein et al., "Taxation without Representation: Peasants, the Central and the Local States in Reform China," China Quarterly, vol. 163, 2000, pp. 742-63. 
Table 7. Correlation of county-level government revenue and expenditure indicators 1999, 2003 and 2005 with various variables

\begin{tabular}{|c|c|c|c|c|c|c|}
\hline 1999 & & $\begin{array}{c}\text { Non-agricult. } \\
\text { econ }\end{array}$ & $\begin{array}{c}\text { Agri econ of } \\
\text { scale }\end{array}$ & PPCl & $\begin{array}{l}\text { PeasBurden } \\
\text { /Revenue }\end{array}$ & Transfers \\
\hline \multirow[t]{2}{*}{ Rev299/Cap } & $\mathrm{R}$ (Pearson) & $.762\left(^{* \star}\right)$ & .109 & $.560\left(^{* *}\right)$ & $-.780\left({ }^{* *}\right)$ & $-.260\left(^{*}\right)$ \\
\hline & $\begin{array}{l}\text { Significance } \\
\text { (2-sided) }\end{array}$ & .000 & .435 & .000 & 0.000 & .043 \\
\hline \multirow[t]{2}{*}{ Exp299/Cap } & $\mathrm{R}$ (Pearson) & .753 (**) $^{*}$ & -.128 & $.373\left(^{* *}\right)$ & $-.648\left(^{* *}\right)$ & .227 \\
\hline & $\begin{array}{l}\text { Significance } \\
\text { (2-sided) }\end{array}$ & .000 & .362 & .003 & 0.000 & .078 \\
\hline \multirow[t]{2}{*}{ RevExp299 } & $\mathrm{R}$ (Pearson) & .048 & $-.409\left(^{* *}\right)$ & $-.414\left(^{* *}\right)$ & $.291\left(^{*}\right)$ & 1 \\
\hline & $\begin{array}{l}\text { Significance } \\
\text { (2-sided) }\end{array}$ & .733 & .002 & .001 & 0.023 & \\
\hline \multicolumn{7}{|l|}{2003} \\
\hline \multirow[t]{2}{*}{ Rev03/Cap } & $\mathrm{R}$ (Pearson) & $\left..780{ }^{* *}\right)$ & $-.329(* *)$ & $.691\left(^{* *}\right)$ & $-.727\left(^{* *}\right)$ & $-.386\left(^{* *}\right)$ \\
\hline & $\begin{array}{l}\text { Significance } \\
\text { (2-sided) }\end{array}$ & .000 & .010 & .000 & 0.000 & .002 \\
\hline \multirow[t]{2}{*}{ Exp03/Сap } & $\mathrm{R}$ (Pearson) & $.677\left(^{* *}\right)$ & $-.413\left({ }^{* *}\right)$ & $.358(* *)$ & $-.734(* *)$ & .219 \\
\hline & $\begin{array}{l}\text { Significance } \\
\text { (2-sided) }\end{array}$ & .000 & .001 & .005 & 0.000 & .090 \\
\hline \multirow[t]{2}{*}{ RevExp03 } & $\mathrm{R}$ (Pearson) & -.225 & -150 & $-.600\left(^{* *}\right)$ & 0.086 & 1 \\
\hline & $\begin{array}{l}\text { Significance } \\
\text { (2-sided) }\end{array}$ & .081 & .248 & .000 & 0.509 & \\
\hline \multicolumn{7}{|l|}{2005} \\
\hline \multirow[t]{2}{*}{ Rev05/Cap } & $\mathrm{R}$ (Pearson) & $.818\left(^{* *}\right)$ & $-.307\left(^{*}\right)$ & $\left..6799^{* *}\right)$ & -0.173 & $-.669\left(^{* \star}\right)$ \\
\hline & $\begin{array}{l}\text { Significance } \\
\text { (2-sided) }\end{array}$ & .000 & .016 & .000 & 0.181 & .000 \\
\hline \multirow[t]{2}{*}{ Exp05/Cap } & $\mathrm{R}$ (Pearson) & $.726\left(^{* *}\right)$ & $-.403\left(^{* *}\right)$ & $.396(* *)$ & -0.182 & $-.349\left(^{* *}\right)$ \\
\hline & $\begin{array}{l}\text { Significance } \\
\text { (2-sided) }\end{array}$ & .000 & .001 & .002 & 0.160 & .006 \\
\hline \multirow[t]{2}{*}{ RevExp05 } & $\mathrm{R}$ (Pearson) & $\left.-.6911^{* *}\right)$ & .072 & $-.747(* *)$ & 0.049 & 1 \\
\hline & $\begin{array}{l}\text { Significance } \\
\text { (2-sided) }\end{array}$ & .000 & .582 & .000 & 0.705 & \\
\hline \multicolumn{7}{|c|}{ * The correlation is significant at a level of 0,05 (2-sided). } \\
\hline
\end{tabular}


Graph 1. Relationship between per capita county revenue (horizontal axis) and transfer payments (vertical axis) 1999 (left) and 2005 (right)

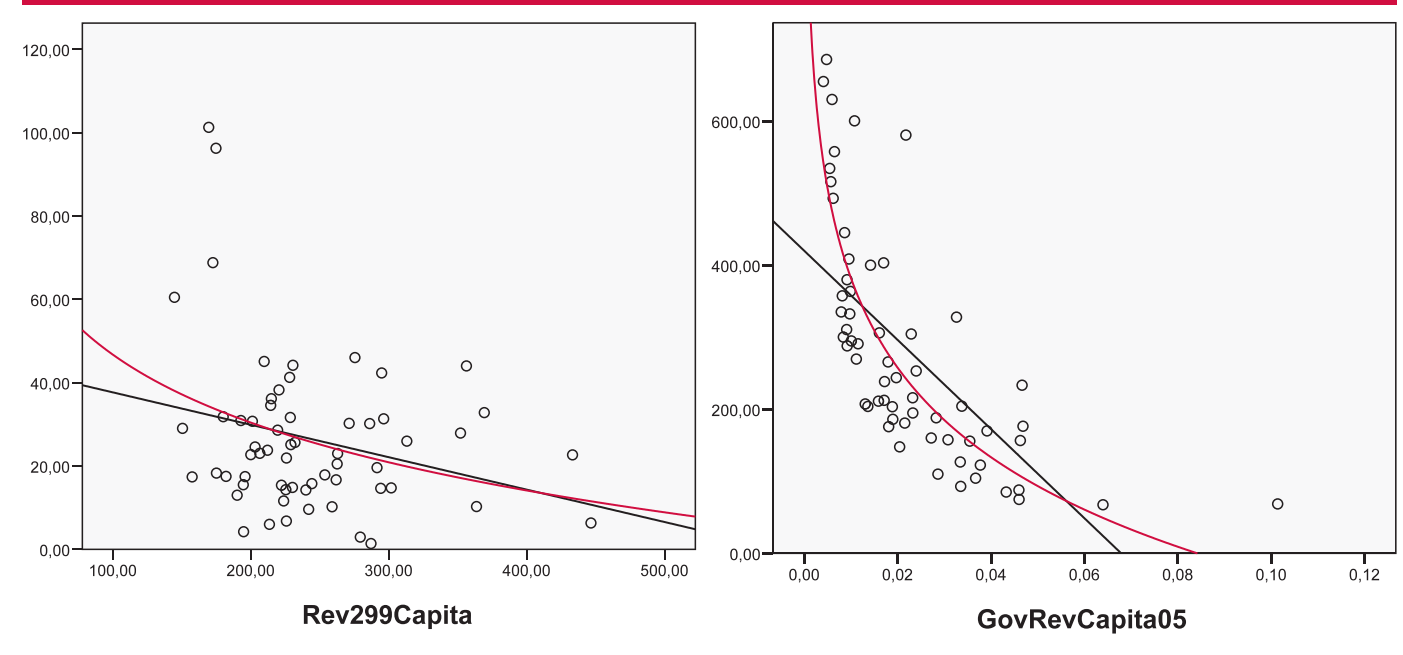

Source: own figure based on Anhui Statistical Yearbook, various years and Anhui Province, RTFR LSG, Anhui Sheng nongcun shuifeigaige qianhou nongmin fudan qingkuang biao, op. cit.

Against this background, an interesting picture emerges with regards to transfer payments (calculated as the percentage of expenditures surpassing revenues). In 1999, the size of transfer payments correlated only weakly with government per capita revenue. Table 7 does not make clear what did determine these transfer payments, but there seems to have been a slight tendency for them to be higher in those counties with a low average PPCI. However, the determinants of transfer payments changed dramatically in the course of the reform, and have increasingly benefited those counties where government per capita revenue is low. Since these also tend to be counties dominated by agriculture and where peasants earn comparatively little, they can be considered structural subsidies. Graph 1 visualises the relationship by government per capita revenue and transfer payments in 2005 and contrasts it with the situation in 1999.

While the variation in per capita revenue explained only 9 percent of the variation in transfer payments $(\mathrm{r}-\mathrm{square}=0.09)$ in 1999, the two variables largely corresponded six years later. In 2005, the size of per capita revenue explained 66.1 percent of the variation in transfer payments $(\mathrm{r}$-square $=0.661)$.

\section{Explaining the changes in peasant income and govern- ment finances}

Comparison of the parameters determining peasant income with government revenues and expenditures shows that there was much continuity, but also some change. $\mathrm{PPCI}$ has been high in relatively industrialised counties, and the average size of the peasant burden did not determine average PPCI. In a similar vein, the parameters determining per capita government revenue and expenditures have remained remarkably constant. On the other hand, however, a regularised fiscal transfer system was clearly being put into place. These observations do not imply that the reform was without impact. After all, the parameters just described can only be changed over an extended period of time, and their resilience should not be interpreted as stasis. They do not deny the far-reaching changes described above, but merely show that the reform has not yet changed the structural foundations of peasant income and government revenue. Hence, it is necessary to go one step beyond the structural foundations, and take a closer look at the changes that occurred. First of all, peasant burden, which had been substantial in northern and central Anhui, was first reduced, and then totally rescinded. Second, PPCI and county-level expenditures increased dramatically between 1999 and 2005, even if government revenue did not. In addition, the changes in PPCI and government receipts and expenditures were far from uniform. The following sections set out to explain these changes. In particular, they seek to determine whether these changes were the intended or unintended consequences of the RTFR, or if they were caused by structural path dependencies strong enough to render the reform policies insignificant. Since the reform proceeded in two stages, the 
Table 8. Determinants of change in PPCI 1999-03 and 2003-2005

\begin{tabular}{|c|c|c|c|c|c|c|}
\hline $99-03$ & $\begin{array}{l}\text { Burden/ } \\
\text { Cap }\end{array}$ & $\begin{array}{l}\text { Primary } \\
\text { GDP/Cap }\end{array}$ & $\begin{array}{l}\text { Secondary } \\
\text { GDP/Cap }\end{array}$ & $\begin{array}{l}\text { Tertiary } \\
\text { GDP/Cap }\end{array}$ & $\begin{array}{c}\text { Wagelncl } \\
\text { Cap }\end{array}$ & $\begin{array}{l}\text { Household } \\
\text { Inc/Cap }\end{array}$ \\
\hline R (Pearson) & $\left..4311^{* *}\right)$ & $.737\left(^{* *}\right)$ & $.310\left(^{*}\right)$ & -.044 & .126 & $.281\left(^{*}\right)$ \\
\hline $\begin{array}{l}\text { Signifiicance } \\
\text { (2-sided) }\end{array}$ & .001 & .000 & .015 & .734 & .337 & .028 \\
\hline \multicolumn{7}{|l|}{ 03-05 } \\
\hline R (Pearson) & .067 & $.4822^{(* *)}$ & -.049 & .088 & $\left..592^{(* *}\right)$ & $.407\left(^{* *}\right)$ \\
\hline $\begin{array}{l}\text { Signifiicance } \\
\text { (2-sided) }\end{array}$ & .607 & .000 & .708 & .501 & .000 & .001 \\
\hline
\end{tabular}

* The correlation is significant at a level of 0,05 (2-sided).

** The correlation is significant at a level of 0,01 (2-sided).

Source: Anhui Statistical Yearbook, various years and Anhui Province, RTFR LSG, Anhui Sheng nongcun shuifeigaige qianhou nongmin fudan qingkuang biao, op. cit.

outcomes of the two stages and their determinants will be compared rather than merely contrasting the status quo ante and the status quo post. In particular, such a comparison might yield further evidence as to why initial reform design had been abandoned. I will first seek to determine whether the changes in PPCI can be explained by the impact of burden reduction, or if they had other causes. In particular, three sets of indicators are tested for their impact on PPCI change between 1999 and 2003, and between 2003 and 2005: the direct impact of the RTFR (measured by the decrease of peasant per capita burden); economic growth in the primary, secondary, and tertiary sectors (measured by the increase of GDP per capita in each sector); and increases in wage- and non-wage per capita income (Table 8). Table 8 yields several interesting results. First, the most important determinant of PPCI growth between 1999 and 2003 was the per capita increase in primary sector GDP. This is not astonishing, since the peasants are of course its main producers. In addition, there is a clear relationship between burden reduction and PPCI growth, although not as might have been expected; in fact, there was a tendency toward more modest PPCI increases where burden was reduced significantly. Obviously, there must be one or more intervening variables that have a positive impact on burden reduction, but a negative impact on PPCI growth. What is important for this analysis, however, is that per capita burden reduction did not have a direct impact on average PPCI increase. This gives further weight to the hypothesis that the "peasant burden problem" mainly affected the low-income strata, while the richer peasants were able to shoulder the extractions reasonably well. Income inequality is substantial not only across Anhui, but also within individual counties. Since the figures for PPCI employed are county averages, they tend to hide these inequalities.

As for the second phase, there was again no connection between the burden level and PPCI increase, as the low correlation coefficient shows. However, Table 8 supports the observation made above that wage income has increasingly become a crucial determinant of PPCI increase. This confirms the findings of an internal report of Anhui's Statistical Bureau, which states that 85 percent of the increase in peasant income has been the result of migrant labour wages. On the other hand, there is a significant correlation between the increase in PPCI and non-wage income as well, which might be due to the fact that peasants have received subsides for planting non-cash crops since 2004, and that agricultural production has increased markedly since 2003 after having fallen to a historical low.

What effect did the two reform phases have on government revenues and expenditures? Again, changes will be tested for the impact of the reform policies and of economic development. In addition, the development of peasant gross income, the primary tax source base until the second reform phase set in, will also be included in the analysis (Table 9). In the first phase of the RTFR, there are some similarities to the impacts observed with respect to peasant burden, which is probably due to the fact that PPCI and government revenue were so closely correlated (see Column 5). Again, 
Table 9. Determinants of change in Government Revenue per Capita, 1999-2003 and 2003-2005

\begin{tabular}{|c|c|c|c|c|c|c|c|}
\hline $99-03$ & $\begin{array}{c}\text { Burden/ } \\
\text { Cap }\end{array}$ & $\begin{array}{l}\text { Primary } \\
\text { GDP/Cap }\end{array}$ & $\begin{array}{l}\text { Secondar } \\
\text { GDP/Cap }\end{array}$ & $\begin{array}{l}\text { Tertiary } \\
\text { GDP/Cap }\end{array}$ & PPCl & $\begin{array}{c}\text { Burden/ } \\
\text { Rev2 } 1999\end{array}$ & $\begin{array}{c}\text { Burd/Rev(2) } \\
99-03\end{array}$ \\
\hline R (Pearson) & $.397\left(^{* *}\right)$ & $.430\left(^{* *}\right)$ & $.360\left(^{* *}\right)$ & -.205 & $.642\left({ }^{* *}\right)$ & -.226 & $-.715\left(^{* *}\right)$ \\
\hline $\begin{array}{l}\text { Signifiicance } \\
\text { (2-sided) }\end{array}$ & .002 & .001 & .004 & .112 & .000 & .080 & \multirow[t]{4}{*}{.000} \\
\hline 03-05 & $\begin{array}{l}\text { Burden/ } \\
\text { Cap }\end{array}$ & $\begin{array}{l}\text { Primary } \\
\text { GDP/Cap }\end{array}$ & $\begin{array}{l}\text { Secondar } \\
\text { GDP/Cap }\end{array}$ & $\begin{array}{l}\text { Tertiary } \\
\text { GDP/Cap }\end{array}$ & $\mathrm{PPCl}$ & $\begin{array}{l}\text { Burden/ } \\
\text { Rev } 2003\end{array}$ & \\
\hline $\mathrm{R}$ (Pearson) & .123 & -145 & $.290\left(^{*}\right)$ & $-.530\left(^{* *}\right)$ & .200 & $-.767\left(^{* *}\right)$ & \\
\hline $\begin{array}{l}\text { Signifiicance } \\
\text { (2-sided) }\end{array}$ & .345 & .264 & .023 & .000 & .121 & .000 & \\
\hline
\end{tabular}

* The correlation is significant at a level of 0,05 (2-sided).

** The correlation is significant at a level of 0,01 (2-sided).

Source: Anhui Statistical Yearbook, various years and Anhui Province, RTFR LSG, Anhui Sheng nongcun shuifeigaige qianhou nongmin fudan qingkuang biao, op. cit.

the less burden was reduced, the more government revenue per capita tended to increase, and the development of primary, rather than secondary, GDP per capita correlated with increases in government revenue. In general, the development of government per capita revenue tended to follow $\mathrm{PPCI}$, which again is not surprising.

In the second phase, however, these variables loose their explanatory power. Government revenue increase is generally correlated neither with burden reduction nor with economic development. This may be due to the fact that the development of per capita revenue during the second phase clearly followed a regional pattern. Revenue in the northwest was further reduced, while increasing in most counties in the south and east. Very probably, different factors underlay these developments. Hence, it might be wise to concentrate on the counties where we would expect the reform to have had an especially significant effect, anticipating that counties with revenue mainly dependent on peasant burden would have been hit the hardest. Astonishingly, this assumption is proven false, at least for the first phase. The percentage of peasant burden in total revenue does not significantly correlate with the development of government per capita revenue during the first phase, and high dependence on peasant burden did not automatically lead to a decrease in government revenue during the first reform phase. In the second phase, however, it was the single most potent variable correlating with the development of revenue. It alone explains nearly 60 percent of the variation in per capita government revenue between 2003 and 2005. Counties relying chiefly on peas- ant burden for revenue clearly faced severe revenue reductions, while those with other sources of revenue did not.

Why does that not seem to hold true during the first phase of the RTFR? Obviously, the assumption underlying this statistical test, namely that the revenue reduction caused by the RTFR is the single most potent factor in the change in government revenue before and after the reform, is wrong. In other words, along with, but rather unrelated to the RTFR, a very significant increase or decrease in other revenue items must have taken place.

This hypothesis is not easy to test, since detailed data on county-level revenue and expenditure items before the reform are not available. However, an analysis of prefecturelevel data might help. Indeed, a close examination reveals two major changes that took place in 2000. First, the northwestern prefecture-level cities of Fuyang and Bozhou saw a major restructuring. In 1999, Fuyang City supervised eight county-level governments ${ }^{(19)}$ and Bozhou City none, but Bozhou was put in charge of three of Fuyang's counties in 2000. ${ }^{(20)}$ The shift does not seem to have been beneficial to the financial situation of these cities. In 2000, their combined receipts fell 29.8 percent compared with 1999, by far the greatest loss any city faced during that crucial period. In what revenue items did these losses materialise?

This brings us to the second point. Analysis reveals that revenue from a budgetary item called the "tax for the adjust-

19. Jieshou City, Linquan, Taihe, Guoyang, Mengcheng, Funan, Yingshang and Lixin Counties. 20. Guoyang, Mengcheng, and Lixin Counties. 
Graph 2. Increase in budgetary revenues and expenditures, Anhui province, county level, 1999-2000 (in percent)

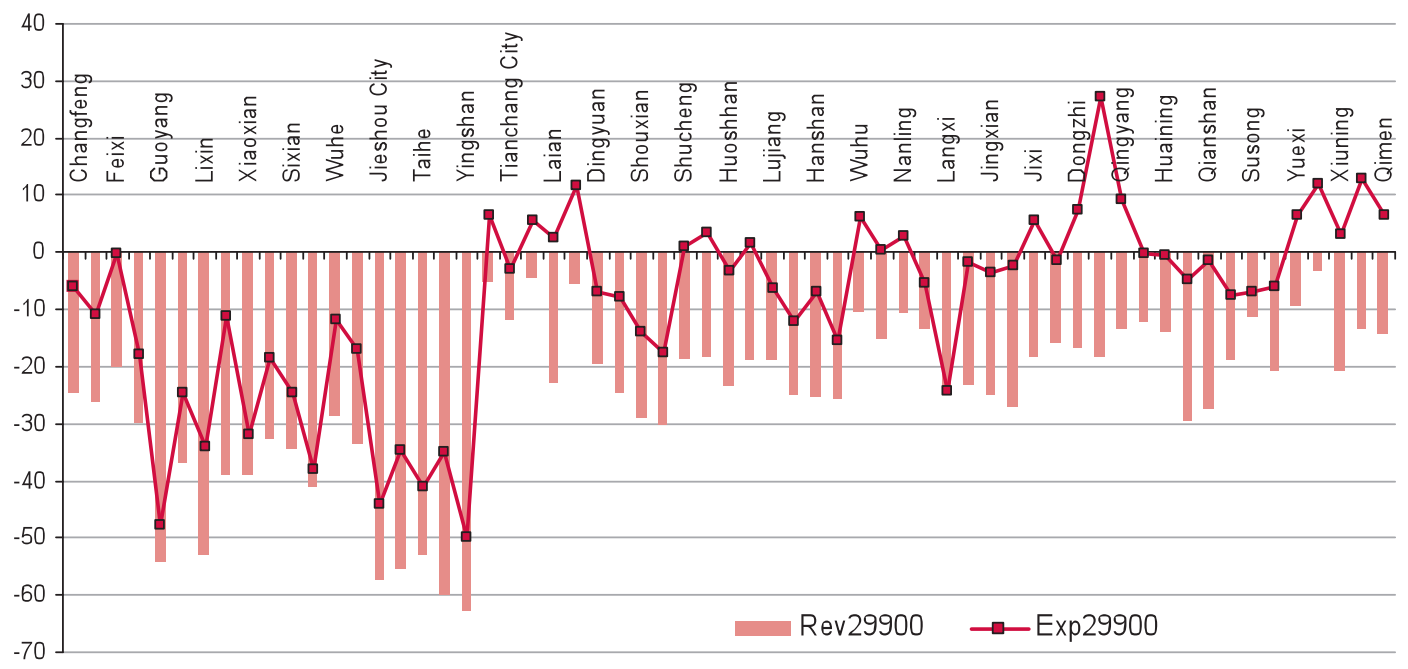

Source: Anhui Statistical Yearbook, 2000 and 2001.

ment of investments in fixed assets" (guding zichan touzi fangxiang tiaojieshui) declined between 88 percent and 99 percent during the same period. The central government implemented this tax in 1991 in response to the investment boom of the 1980s. Requiring investors to pay amounts ranging from 5 to 15 percent of their fixed investments to the local governments, this tax was a macro-economic steering instrument. While it might have been an appropriate means to counter over-investment and cool down the overheated economy at the time, the tax quickly became dysfunctional as local economic development stagnated and governments were encouraged to woo investors into their localities. ${ }^{(21)}$

The decline in receipts from this tax was significant, given that these receipts made up an average of almost 10 percent of prefecture-level budgetary revenue (and was as high as 15.4 percent in one prefecture). Of the six cities whose dependence on this tax surpassed the average, only two managed to increase their budgetary revenue during this period, while the others stagnated (Suzhou; $+0.6 \%$ ) or even declined (Xuancheng -2.8\%; Maanshan -12.1\%; Bozhou and Fuyang combined: -29.8\%). The two cities that increased their budgetary revenue despite above-average dependence on this tax were more developed, and clearly managed to shift the burden to the industrial sector; receipts from enterprise income tax in both Wuhu and Tongling City tripled within just one year. It is remarkable that this reform has not been researched at all. The signif- icance of the Adjustment Tax to the budgets of the more developed regions can be likened to that of the agricultural tax in the agricultural regions, and its abolition must have had a great impact on both government finances and enterprise burden.

In summation, a rather complex picture emerges in which all county-level governments faced revenue losses, but for different reasons: for agriculture-heavy counties, the increase in agricultural tax revenue in the first reform phase could not offset the losses resulting from the abolition of agriculture-related levies and fees, and industry-heavy counties only avoided similar losses from the abolition of the Adjustment Tax by shifting the revenue burden to the industrial sector. If receipts from the santi wutong and the education fee are figured in, every single county faced revenue losses between 1999 and 2000 (see Graph 2). The fact that budgetary growth rates were negative in only six of 17 prefecture-level governments between 1999 and 2000 shows that they were relatively able to shoulder this "double burden."

As can be seen, the losses are most significant in poor north-western Anhui (in the left quadrant of the graph), particularly in counties that were affected by the territorial restructuring measures and that could not shift the "double

21. Xiang Huaicheng, "Jin yi bu tiaozheng jiji caizheng zhengce de shishi lidu he juti cuoshi" (Further adjustment of implementation efforts and concrete measures of a pro-active fiscal policy), Renmin Ribao, 15 July 1999. 
Graph 3. Percentage of budgetary expenditures surpassing budetary revenues, Anhui province, county level, 1996-2005 (in percent)

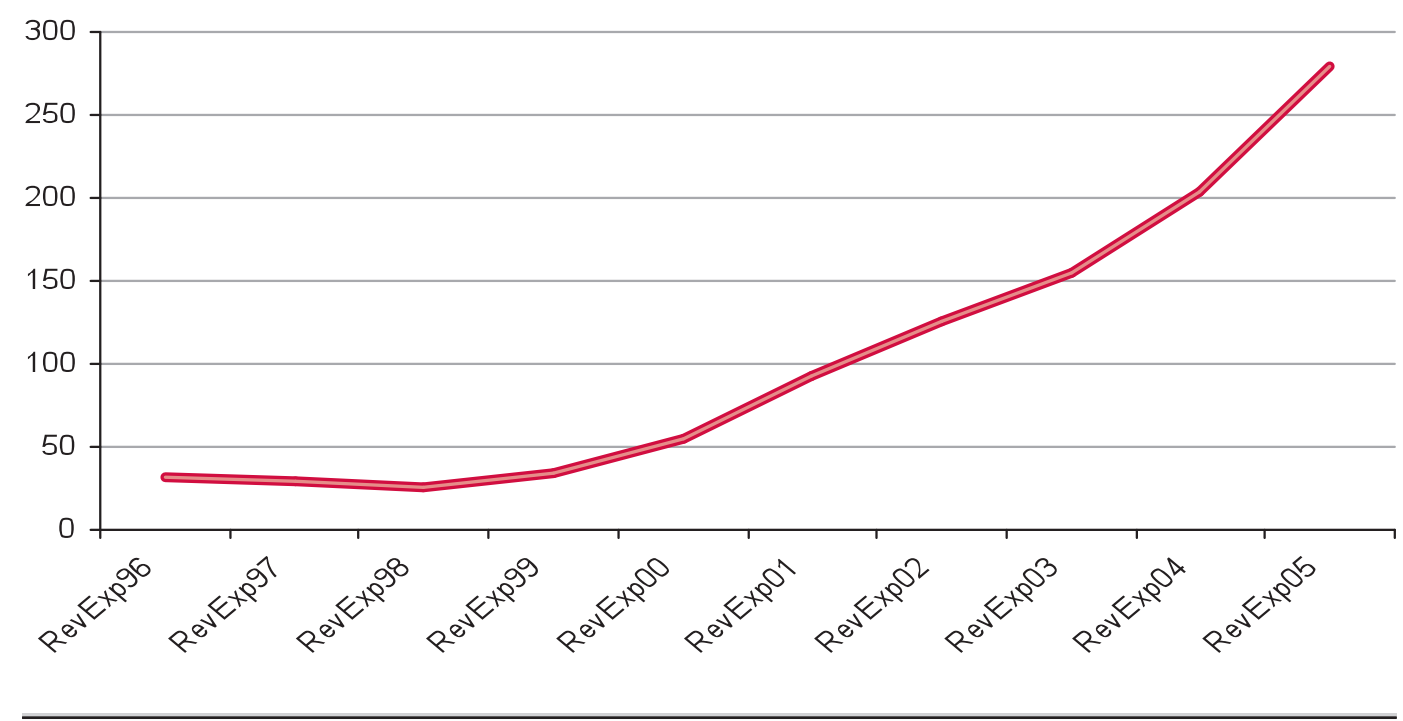

Source: Anhui Statistical Yearbook, various years.

burden" of the Agricultural and Adjustment Tax reforms on a developed industry. Not incidentally, the eight counties most severely affected were listed among the least developed in almost all indicators in Anhui's Statistical Yearbook 2006, with four of them qualifying as "national level poor counties." (22) The effect of abolition of the investment adjustment tax is an issue that merits further attention. Unfortunately, due to lack of information and data, this topic cannot be pursued further without conducting additional fieldwork.

What is important for this study is that while expenditure increases and decreases closely mirrored the development of revenues during that phase, a regularised fiscal balancing mechanism was gradually put into place later on. As Graph 3 below shows, the gap between revenues and expenditures steadily increased, especially after the year 2000. In 2004, the year when the agricultural tax began to be rescinded, the expenditure-revenue ratio made another substantial leap. In 2003, one year before it was scrapped, the agricultural tax made up an average of 34 percent of county-level revenue, and local governments had to be compensated for this loss.

Consequently, all counties were able to significantly increase expenditure despite declining revenues throughout the two reform phases. This brings us to the final question, concerning expenditures.

\section{Expenditures}

Given that the centre's policy focus has shifted to rural development, and given that a large portion of transfer payments are directly or indirectly financed by the centre, we would expect to see this shift in foci mirrored in the expenditure structure. In general, expenditures for agricultural development, education, health, and social security should increase faster than those for other, non-rural development-oriented items. Furthermore, we would expect the alleged success in personnel reduction to be reflected in decreasing or at least stagnant administrative expenditure. In addition, it has been shown above that revenue-poor counties benefited most from the transfer payments. Since, not incidentally, revenue poverty correlated highly with peasant poverty, we would expect the shift in expenditure to be even stronger in these counties. Since expenditure increased in all counties between 1999 and 2005, it would be useless to look only at expenditure increases. Hence, the following section analyses the percentage of particular expenditure items within total expenditures, beginning with the identification of general trends in expenditure priorities on the aggregate city and county levels. It then proceeds to statistically analyse the impact of expenditure increases on the expenditure structure for all 61 counties in general and on their dependence on transfer payments.

22. Linquan, Funan, Yingshang and Lixin county; see ATNJ 2006 
Graph 4. Expenditures on various social services as percent of total expenditures, Anhui province, aggregate city level, 1999-2005

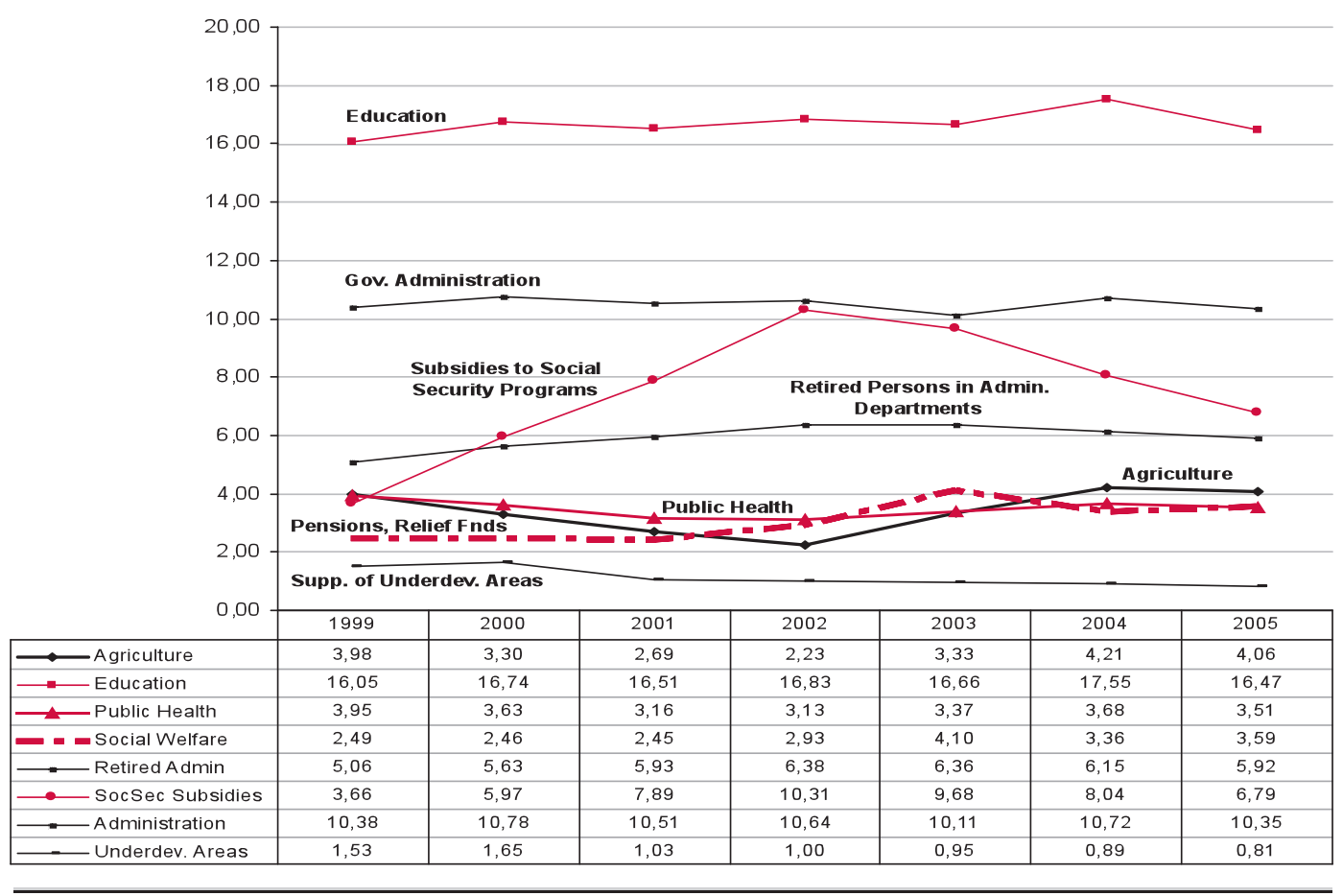

Source: Anhui Statistical Yearbook, various years.

The following sections attempt to trace the development of priority changes in public service spending during the period in question. Changed spending patterns are treated as an indicator of local government commitment to improving rural development, although it should by no means be assumed that increased public spending automatically leads to better services in a particular sector. ${ }^{(23)}$

As Graph 4 shows, in terms of total budgetary expenditures, education expenses have remained rather stable in Anhui Province. If the cities are excluded, the ratio is of course higher, yet displays a very similar trend (2000: 29.2\%; 2002: 31.5\%; 2005: 27.0\%). Of course, absolute expenditure for education has increased steeply, but so has expenditure on the other items. Obviously, there has been no strong shift in priorites for this item. This is astonishing given the fact that the cost of providing compulsory education was shifted from the township to the county level in 2001 and must, at least in part, ${ }^{(24)}$ be represented in budgetary expenditure figures. If the government kept its promise to shoulder a larger portion of rural education expenditure, that is not reflected in these figures.
The other social service-related expenditure items have also remained quite stable over time. The only exception is subsidies to social security programs, which declined sharply between 1999 and 2002, with a less marked decline since then. Remarkably, aggregate city-level expenditures on health, support for underdeveloped areas, pensions, and agriculture are far lower than the expenditures for retirement pensions for administrative personnel. Similarily, the provincial government spends only slightly more on subsidies for social security programs for millions of workers and peasants than it does on pensions for former civil servants. It should be noted, however, that the expenditure share for government administration steadily de-

23. Education is a good example. While scholars and the media alike lament the decline in the quality of education in rural China, government statistics show that education is the biggest expenditure item in Anhui Province, making up around 16 percent of aggregate city-level expenditure and around one third of county-level expenditure. However, most of this expenditure goes toward teachers' salaries and not toward the improvement of educational facilities or teacher training. In addition, the largest portion of such expenditure is spent on secondary and tertiary education, not on rural primary education.

24. Part of the cost may be met by earmarked funds received from the centre and that do not pass through budgetary channels. 
Table 10. Correlation of change in expenditure structure with county-level government revenue and expenditure indicators 2000-2003 and 2003-2005 with various variables

\begin{tabular}{|c|c|c|c|c|c|c|c|c|c|}
\hline & 00-03 & $\begin{array}{l}\text { Capital } \\
\text { Constr. }\end{array}$ & Agri & Edu & SocSec & Admin & Pubsec & Other & \\
\hline \multirow[t]{2}{*}{$\begin{array}{l}\text { Exp/Cap } \\
00-03\end{array}$} & $\mathrm{R}$ ( Pearson) & -.008 & .108 & $|-.440(* *)|$ & .017 & -.078 & -125 & .041 & \\
\hline & $\begin{array}{l}\text { Significance } \\
\text { (2-sided) }\end{array}$ & .958 & .406 & .000 & .897 & .551 & .338 & .751 & \\
\hline \multirow[t]{3}{*}{$\begin{array}{l}\text { Rev/Exp } \\
2003\end{array}$} & $\mathrm{R}$ ( Pearson) & -.015 & .057 & -.133 & -.057 & -.213 & $-.364\left({ }^{* *}\right)$ & -.064 & \\
\hline & $\begin{array}{l}\text { Significance } \\
\text { (2-sided) }\end{array}$ & .926 & .665 & .306 & .664 & .099 & .004 & .623 & \\
\hline & 03-05 & $\begin{array}{l}\text { Capital } \\
\text { Constr. }\end{array}$ & Agri & Edu & SocSec & Admin & Pubsec & Other & Health \\
\hline \multirow[t]{2}{*}{$\begin{array}{l}\text { Exp/Cap } \\
03-05\end{array}$} & $\mathrm{R}$ ( Pearson) & -.140 & $\begin{array}{r}- \\
.297\left(^{*}\right) \\
\end{array}$ & -.216 & $-.259\left(^{*}\right)$ & -.045 & -.217 & $.338\left(^{* *}\right)$ & .162 \\
\hline & $\begin{array}{l}\text { Significance } \\
\text { (2-sided) }\end{array}$ & .293 & .020 & .094 & .044 & .732 & .093 & .008 & .214 \\
\hline \multirow[t]{2}{*}{$\begin{array}{l}\text { RevExp } \\
2005\end{array}$} & $\mathrm{R}$ ( Pearson) & $.269\left(^{*}\right)$ & .101 & $.358\left(^{* *}\right)$ & -.112 & .036 & -.079 & -.134 & $.286\left({ }^{*}\right)$ \\
\hline & $\begin{array}{l}\text { Significance } \\
\text { (2-sided) }\end{array}$ & .041 & .441 & .005 & .389 & .784 & .546 & .304 & .025 \\
\hline
\end{tabular}

clined at the aggregate city and the county level alike. However, as was the case with all other expenditures, absolute expenses increased rather sharply ( 18.2 percent between 2000 and 2001 alone, and 30.0 percent between 2003 and 2004).

Statistical analysis confirms that neither the general increase in expenditure nor the increase in transfer payments affected the expenditure structure at the county level. As a general rule, increased expenditure on all the items discussed so far followed the general increase in expenditure, with no particular increases evident during the first phase (Table 10).

Table 10 contrasts the change in expenditure structures during the two phases ${ }^{(25)}$ with corresponding increases in budgetary spending and transfer payments. In the first phase, the slight changes in expenditure priorities observed above cannot be explained by either the amount of expenditures or the size of transfer payments. The only exception is education, where expenditures tended to increase at a lower rate than overall spending. In addition, there was a slight tendency for counties receiving larger transfer payments to spend less on public security. In the second phase, the picture changed somewhat. Expenditure-rich counties display a comparative neglect of spending on agriculture and social security, although the corelation is quite weak. However, they tend to spend more on items that are not individually listed in the yearbook. Counties that benefited from large transfer payments in 2005 display a tendency, albeit a slight one, to focus more on education and health. ${ }^{(26)}$

In conclusion, the assumptions put forward at the beginning of this section have not been proven true. With the possible

25. The change in expenditure structure denotes the percentage change of each expenditure item in total expenditure calculated between 2000 and 2003 for the first phase, and 2003 and 2005 for the second.

26. Seemingly, capital construction has become a focus item as well. However, the correlation is mainly caused by four extremely large values. If these are omitted, the relationship ceases to exist. 
exception of education, where there was a slight tendency for counties with large transfer payments to increase relative spending, the central government's focus on rural development was not reflected in changed expenditure structures. Again, this does not mean that nothing happened. First, expenditure on items related to social services tended to increase along with general increase in expenditure, so additional money was definitely being spent. Second, as Brandt et al. point out, much investment in rural infrastructure was being made via earmarked transfers from the centre that do not appear in the regular budget. ${ }^{(27)}$

\section{Conclusion}

Summing up the observations made in the previous sections, the following picture emerges. On the aggregate level, the Rural Tax and Fee Reform has not had any impact at all on aggregate county-level PPCI. Of course, this does not imply that the reform did not achieve anything in this respect; it is very likely that poor peasants did indeed benefit from the reduction in regular and irregular extractions. As Chen Xiwen has shown, the regressive nature of the peasant burden had its strongest effect on the poorest peasant strata, which lost an average of more than 37 percent of its gross revenue to taxes and fees. ${ }^{(28)}$ For the richest strata, such deductions amounted to less than 5 percent. What the data do imply, however, is that the reduction of income inequality achieved by the reform was outstripped by the increase in PPCI in Anhui's more prosperous regions. In other words, on the aggregate county level, it was not the RTFR that increased peasant incomes, but economic factors such as a growing primary sector in wealthy regions and income from non-agricultural activities.

As for development of fiscal revenues, the analysis has shown that two non-interrelated factors were chiefly responsible: first, the increase in peasant income, and second, tax reductions. Low PPCI tended to cause low revenues, and these revenues were even further reduced by the RTFR and the tax adjustment reform. Hence, initially poor counties became even poorer, while wealthier counties were able to shoulder the losses incurred through the reform by mobilising other revenue. Geographically, this led to an amplification of Anhui's south-north divide. Since the initial reform design had not anticipated transfer payments and basically demanded that counties implement austerity policies to offset losses, the northern counties were even more disadvantaged. Their reluctance and probably also inability to implement such measures may be one of the chief reasons for the failure of the initial reform design. Fortunately, abolition of the agricultural tax forced the central government to address this situation, and a mechanism of transfer payments benefited revenue-poor counties over their wealthier counterparts. In fact, every single county spent more in 2005 than it earned, but the margin underlying the size of transfer payments was huge.

Remarkably, the centre has not taken advantage of its increased and unintended financial involvement in the reform to influence the expenditure structure of the subsidised counties. While comparatively higher spending on items related to the provision of social services would have been expected, especially in those counties profiting most from transfer payments, this assumption was proven false. Either this change in focus was operationalised outside the regular budget by means of earmarked transfers, as Brandt et al. have found, or other factors related to the structure of central-local relations were at work. $\bullet$

$\begin{array}{ll}\text { Glossary } & \\ \text { nongcun shuifei gaige } & \text { 農村税費改革 } \\ \text { peitao gaige } & \text { 配套改革 } \\ \text { san nong wenti } & \text { 三曹問題 } \\ \text { zhuti gaige } & \text { 主體改革 } \\ \text { peitao gaige } & \text { 配套改革 } \\ \text { nongmin wenti } & \text { 曹民閴題 } \\ \text { nongcun wenti } & \text { 蕽村問題 } \\ \text { nongye wenti } & \text { 曹業問題 } \\ \text { dongbu } & \text { 東部 } \\ \text { zhongbu } & \text { 中部 } \\ \text { Guding zichan touzi fangxiang tiaojieshui } & \text { 固定資產投資方 } \\ & \text { 向調解税 } \\ \text { santi wutong } & \text { 三提五統 }\end{array}$

27. Loren Brandt et al., "China- Rural Public Finance. The Township Perspective," op. cit.

28. Chen Xiwen, Zhongguo xian xiang caizheng yu nongmin zengshou wenti yanjiu (Research on public finances in China's counties and townships and the problem of increasing peasant income), 2003 